\title{
SISTEM INFORMASI MONITORING BIMBINGAN SKRIPSI BERBASIS WEB RESPONSIF PADA PROGRAM STUDI SISTEM INFORMASI UNIVERSITAS MURIA KUDUS
}

\author{
Dimyati Utoyo $^{1}$, Wiwit Agus Triyanto ${ }^{2}$, Syafiul Muzid ${ }^{3}$ \\ ${ }^{123}$ Program Studi Sistem Informasi Fakultas Teknik Universitas Muria Kudus
}

\section{Article Info:}

Dikirim: Oktober 2018

Direvisi: November 2018

Diterima: Desember 2018

Tersedia Online: Desember 2018

Penulis Korespondensi:

Syafiul Muzid

Program Studi Sistem Informasi,

Fakultas Teknik,

Universitas Muria Kudus,

Kudus, Indonesia

Email: syafiul.muzid@umk.ac.id

\begin{abstract}
Abstrak: Skripsi merupakan salah satu mata kuliah akhir yang wajib bagi mahasiswa untuk bisa menyelesaikan studinya secara tuntas. Akan tetapi, selama proses pengerjaan skripsi terkadang terjadi masalah mulai dari pengajuan proposal hingga sidang laporan. Riwayat bimbingan yang tidak terdokumentasi dengan baik menyulitkan dosen pembimbing untuk melakukan evaluasi berdasarkan bimbingan sebelumnya. Setiap skripsi mempunyai batas waktu tertentu, apabila pengerjaan melebihi waktu yang ditentukan resikonya adalah perpanjangan semester hingga yang paling terburuk adalah drop out. Pengawasan yang lemah juga menyebabkan proses skripsi tidak sesuai jadwal. Sehingga butuh suatu sistem monitoring bimbingan skripsi yang dapat mengontrol proses bimbingan skripsi mahasiswa.
\end{abstract}

Kata kunci: sistem monitoring, sistem bimbingan skripsi, monitoring skripsi.

\begin{abstract}
Thesis is one of the final courses that is mandatory for students to complete their studies thoroughly. However, during the process of working on a thesis, problems sometimes occur ranging from submission of proposals to trial reports. A history of guidance that is not well-documented makes it difficult for supervisors to conduct evaluations based on previous guidance. Each thesis has a certain time limit, if the execution exceeds the specified time the risk is the extension of the semester until the worst is drop out. Weak oversight also causes the thesis process not on schedule. So that it requires a thesis guidance monitoring system that can control the student's thesis guidance process.
\end{abstract}

Keywords: monitoring system, thesis guidance system, thesis monitor. 


\section{PENDAhUluaN}

Skripsi atau tugas akhir merupakan suatu syarat bagi kelulusan seorang mahasiswa strata 1 (sarjana) dari perguruan tinggi. Skripsi merupakan mata kuliah akhir yang harus diselesaikan oleh mahasiswa perguruan tinggi swasta ataupun perguruan tinggi negeri sehingga dianggap telah pantas mendapatkan gelar sarjana. Dalam proses penelitian skripsinya, mahasiswa menemukan masalah dalam suatu bidang yang ditekuni dan membahasnya sesuai dengan ilmu yang telah didapatkan di dalam atau di luar perkuliahan.

Pada Program Studi Sistem Informasi Fakultas Teknik Universitas Muria Kudus, proses bimbingan penyusunan skripsi melibatkan beberapa pihak, yaitu koordinator skripsi, dosen pembimbing, dan mahasiswa bimbingan. Proses yang dilakukan secara tatap muka langsung antara dosen pembimbing dengan mahasiswa. Setiap sesi bimbingan skripsi dicatat di buku bimbingan yang dibawa oleh mahasiswa berisi informasi tanggal bimbingan, keterangan bimbingan, dan paraf dari dosen pembimbing.

Dalam pelaksanaannya sering terjadi masalah, misalnya dosen pembimbing tidak mempunyai catatan mengenai sampai tahapan mana mahasiswa yang telah melakukan bimbingan. Hal ini dapat terjadi karena faktor komunikasi yang kurang baik diantara mahasiswa bimbingan dan dosen pembimbing walaupun dibuat grup Whatsapp sebagai wadah komunikasi. Selain itu, pencatatan proses hanya dilakukan oleh satu pihak, yaitu di buku bimbingan mahasiswa sehingga dosen tidak ada prosedur yang baik bagaimana dosen pembimbing dapat mengetahui catatan bimbingan yang telah diulas sebelumnya sebagai bahan pertimbangan untuk bimbingan yanng akan dilakukan.

Beberapa hal yang menjadi masalah juga dialami mahasiswa. Tidak adanya informasi tentang sisa waktu pengerjaan skripsi terkadang membuat mahasiswa tidak terdorong untuk lebih bersemangat mengerjakan skripsi dengan lebih displin. Informasi tentang jadwal bimbingan dan perubahannya yang belum sepenuhnya mudah diakses. Pengumuman jadwal dicetak operator di kertas dan ditempelkan di papan pengumuman kantor program studi. Selain itu, operator yang juga berstatus mahasiswa magang, menyampaikan informasi tersebut ke grup obrolan Whatsapp mahasiswa. Masalah lain yang juga sering dialami mahasiswa adalah saat laptop untuk mengerjakan skripsi mati, rusak, atau sebagainya, sehingga menyebabkan berkas skripsi tidak bisa diselamatkan.

Permasalahan akan bertambah parah jika mahasiswa tidak atau lupa melakukan pencadangan data. Hal tersebut akan menyebabkan bimbingan tertunda lebih lama dari target waktu awal, karena mahasiswa terpaksa mengulang dari awal pengerjaan skripsi. Bimbingan mahasiswa sering tidak teratur, pengelolaan waktu yang kurang baik sangat mempengaruhi perkembangan skripsi mahasiswa. Terkadang satu minggu rajin bimbingan, kemudian absen mingguan sampai bulanan.

Beberapa hal di atas tentu merugikan bagi mahasiswa, terkait waktu, jadwal, berkas yang hilang, pengingat, dan hasil seminar proposal. Masalah-masalah tersebut menyebabkan pengerjaan skripsi menjadi lebih lambat sehingga menunda skripsi selesai tepat waktu dan resiko terburuk jika tidak tuntas dari batas waktu yang ditentukan adalah drop out.

Oleh sebab itu, dalam penelitian yang akan dilakukan penulis, sistem informasi yang akan dirancang untuk mengganti sistem sebelumnya akan memudahkan koordinator skripsi, dosen pembimbing, dan mahasiswa dalam melakukan proses bimbingan skripsi di Program Studi Sistem Informasi Univiersitas Muria Kudus.

\section{METODOLOGI PENELITIAN}

Beberapa penelitian lain telah dilakukan terkait dengan pengembangan sistem informasi skripsi. Perdana menjelaskan tentang aplikasi bimbingan skripsi online. Hasil penelitiannya menyebutkan bahwa sistem informasi bimbingan skripsi dapat memberikan kemudahan bagi mahasiswa dan dosen pembimbing sehingga dapat memaksimalkan waktu proses bimbingan [1]. Sedangkan Ramayasa dkk menjelaskan dengan adanya sistem monitoring pengerjaan skripsi mampu memberikan informasi mengenai perkembangan pengerjaan skripsi mahasiswa, hasil bimbingan, estimasi kelulusan, dan kendala yang dihadapi mahasiswa dalam mengerjakan skripsi sehingga mahasiswa dapat menyelesaikan skripsi tepat waktu [2].

Ramadhan dkk menyatakan bahwa sistem informasi monitoring skripsi dapat memudahkan dosen pembimbing dalam memonitoring ketidakdisplinan mahasiswa dalam bimbingan skripsi sehingga dosen pembimbing dapat menentukan langkah yang tepat dalam membimbing mahasiswa tersebut [3]. Utariani dan Herkules menjelaskan bahwa sistem monitoring bimbingan skripsi menjadi salah satu solusi yang dapat membantu proses bimbingan dan membantu mahasiswa yang sedang mengambil skripsi dan dosen juga tetap bisa mengoreksi skripsi mahasiswa, sehingga proses bimbingan berjalan lancar hingga selesai [4].

Berdasarkan penelitian-penelitian diatas dapat disimpulkan bahwa monitoring skripsi sangat perlu dilakukan agar mahasiswa dapat menyelesaikan skripsi sesuai dengan batas waktu yang ditentukan sehingga mahasiswa dapat lulus tepat waktu. Penggunaan sistem informasi berbasis web secara online sangat dibutuhkan pada saat ini sehingga monitoring dapat dilakukan dari jarak jauh, kapanpun dan dimanapun. Dalam penelitian ini akan dikembangan suatu sistem informasi berbasis web yang dapat digunakan untuk monitoring bimbingan skripsi mahasiswa sehingga target lulus tepat waktu dapat tercapai. Metode-metode dalam penelitian digunakan untuk mendukung tujuan penelitian ini dapat dicapai.

\subsection{Metode Pengumpulan Data}

Metode pengumpulan data dilakukan untuk memperoleh data yang relevan, reliable, dan akurat. Berikut ini beberapa metode pengumpulan data yang digunakan dalam penelitian: 
- Observasi dilakukan dengan cara mengamati proses pendaftaran skripsi, pengajuan judul, bimbingan skripsi sampai dengan pelaksanaan ujian skripsi di Program Studi Sistem Informasi.

- Wawancara dilakukan dengan Koordinator Skripsi yaitu dosen yang ditunjuk oleh Ketua Program Studi (Kaprodi) untuk mengelola dan bertanggungjawab terhadap proses skripsi di program studi, Kaprodi, beberapa dosen dan mahasiswa yang sedang melaksanakan skripsi atau sudah menyelesaikan skripsi.

- Studi Pustaka termasuk dalam teknik pengumpulan sumber data sekunder, yaitu sumber data yang didapatkan tidak secara langsung. Dalam hal ini studi pustaka meliputi buku-buku dan literatur terkait masalah yang sedang dibahas dan juga studi dokumentasi yaitu mengumpulkan data dari formulir-formulir yang digunakan selama proses skripsi berlangsung dari mulai hingga selesai.

\subsection{Metode Pengembangan Sistem}

Metode pengembangan sistem yang digunakan dalam Sistem Informasi Monitoring Bimbingan Skripsi adalah model waterfall yaitu model pengembangan yang menggambarkan secara sistematis dan terurut meliputi tahapan analisa kebutuhan sistem (requirement analysist), perancangan sistem (system design), pengembangan sistem (system development), pengujian sistem (integration and testing) dan penyerahan sistem ke pengguna dan perawatan sistem (operation and maintenance). Model ini merupakan model pengembangan sistem yang paling banyak digunakan dikarenakan tahapannya yang teratur setiap langkahnya [5].

\subsection{Analisa Sistem}

Berdasarkan analisa dari masalah yang terjadi maka aktor yang terlibat dalam Sistem Informasi Monitoring Bimbingan Skripsi adalah sebagai berikut:

a) Administrator yang bertugas mengelola data koordinator skripsi, data dosen, data operator, dan ketua program studi.

b) Ketua Program Studi (Kaprodi) dapat melihat daftar mahasiswa yang sedang mengambil skripsi, melihat judul skripsi, hasil seminar proposal, hasil sidang skripsi dan ulang, dan memantau perkembangan skripsi.

c) Koordinator Skripsi yang bertugas melakukan pembagian dosen, penjadwalan seminar proposal dan sidang skripsi, mengelola data skripsi dan perkembangan skripsi, serta mengelola hasil seminar dan nilai skripsi.

d) Operator adalah petugas yang menangani pendaftaran skripsi berupa pengecekan berkas, berkas seminar proposal dan sidang skripsi, dan mengelola informasi pengumuman.

e) Dosen dapat mengelola jadwal bimbingan, melihat perkembangan bimbingan, dan menyetujui pengajuan judul oleh mahasiswa.

f) Mahasiswa dapat melakukan pendaftaran skripsi dengan mengunggah berkas, mengajukan judul, mengunggah perkembangan skripsi, mendaftar seminar proposal, dan mendaftar sidang skripsi.

Aktor-aktor tersebut melakukan beberapa aktivitas dalam Sistem Informasi Monitoring Bimbingan Skripsi sebagai berikut:

a) Mahasiswa dapat mencari judul-judul yang sudah pernah diajukan oleh mahasiswa lain sehingga dapat mengurangi tingkat plagiarisme atau sebagai referensi dalam membuat judul skripsi.

b) Mahasiswa yang telah mengambil skripsi pada saat registrasi Kartu Rencana Studi (KRS) dapat melakukan pendaftaran melalui sistem dengan melengkapi berkas persyaratan yang ada dicek oleh petugas Operator.

c) Koordinator Skripsi membagi dosen pembimbing kepada mahasiswa yang telah mendaftar skripsi.

d) Mahasiswa yang telah memiliki Dosen Pembimbing (Dosbim) dapat mengajukan judul untuk disetujui oleh Dosbim.

e) Judul yang telah disetujui kemudian dibuat proposalnya dan dikonsultasikan kepada Dosbim. Kemudian Mahasiswa mendaftar seminar proposal melalui sistem dengan melengkapi berkas persyaratan yang dicek oleh Operator.

f) Koordinator Skripsi membuat jadwal seminar proposal dan menentukan dosen penguji seminarnya.

g) Dosen penguji bertugas menguji konsep dan isi dari proposal yang diajukan oleh Mahasiswa.

h) Proposal yang disetujui maka akan dilanjutkan ke tahap pelaksanaan skripsi dimana Mahasiswa mulai melakukan konsultasi bimbingan kepada Dosbim masing-masing.

i) Selama proses konsultasi bimbingan skripsi, Mahasiswa harus meng-upload perkembangan bimbingan nya melalui sistem sehingga dapat mudah dipantau oleh Dosbimnya.

j) Setelah proses bimbingan selesai, Mahasiswa dapat mendaftar sidang skripsi melalui sistem dengan melengkapi berkas persyaratan yang dicek oleh Operator.

k) Mahasiswa yang telah mendaftar sidang skripsi akan dijadwalkan oleh Koordinator Skripsi serta penentuan dosen pengujinya.

1) Sidang skripsi dilaksanakan sesuai jadwal dan nilai sidang diupload oleh setiap dosen pengujian melalui sistem yang dapat dipantau oleh Koordinator Skripsi.

m) Jika hasil sidang skripsi dinyatakan lulus maka status skripsi akan berubah menjadi selesai sedangkan jika tidak lulus maka akan dilakukan penjadwalan sidang ulang oleh Koordinator Skripsi. 


\section{HASIL DAN PEMBAHASAN}

\subsection{Perancangan Sistem}

Setelah proses analisa yang telah dilakukan kemudian dilanjutkan tahap perancangan sistem menggunakan diagram Unified Modelling Language (UML). Unified Modeling Language (UML) adalah suatu bahasa permodelan untuk membangun perangkat lunak yang dibangun dengan menggunakan teknik pemrograman berorientasi objek. Desain sistem terdiri atas perancangan antarmuka, estetika, konten, navigasi, arsitektur, komponen. Rancang bangun dalam penelitian ini menggunakan perancangan berorientasi objek (UML) [6].

Diagram yang dihasilkan pada proses analisa adalah diagram usecase, diagram class, diagram sekuen, diagram aktivitas, dan diagram status. Diantara diagram-diagram tersebut adalah diagram usecase. Diagram usecase adalah diagram yang mendeskripsikan interaksi antara satu atau lebih aktor dengan sistem informasi yang akan dibuat [7]. Diagram usecase menjelaskan alur bisnis dari proses pendaftaran skripsi, pembagian dosen pembimbing, pelaksanaan seminar proposal, proses bimbingan skripsi dan pemantauan bimbingan, pendaftaran dan pelaksanaan sidang skripsi.

Gambar 1 menjelaskan diagram usecase yang dihasilkan dalam proses analisa sistem yang melibatkan 6 (enam) aktor yaitu Administrator, Kaprodi, Koordinator Skripsi, Operator, Dosen dan Mahasiswa. Setiap aktor tersebut memiliki hak akses yang berbeda-beda sesuai dengan proses bisnis yang dapat dilakukan oleh aktor tersebut. Proses bisnis yang terlibat dalam diagram usecase adalah sebanyak 28 (dua puluh delapan) usecase. Setiap usecase dapt diakses oleh aktor sesuai haknya.

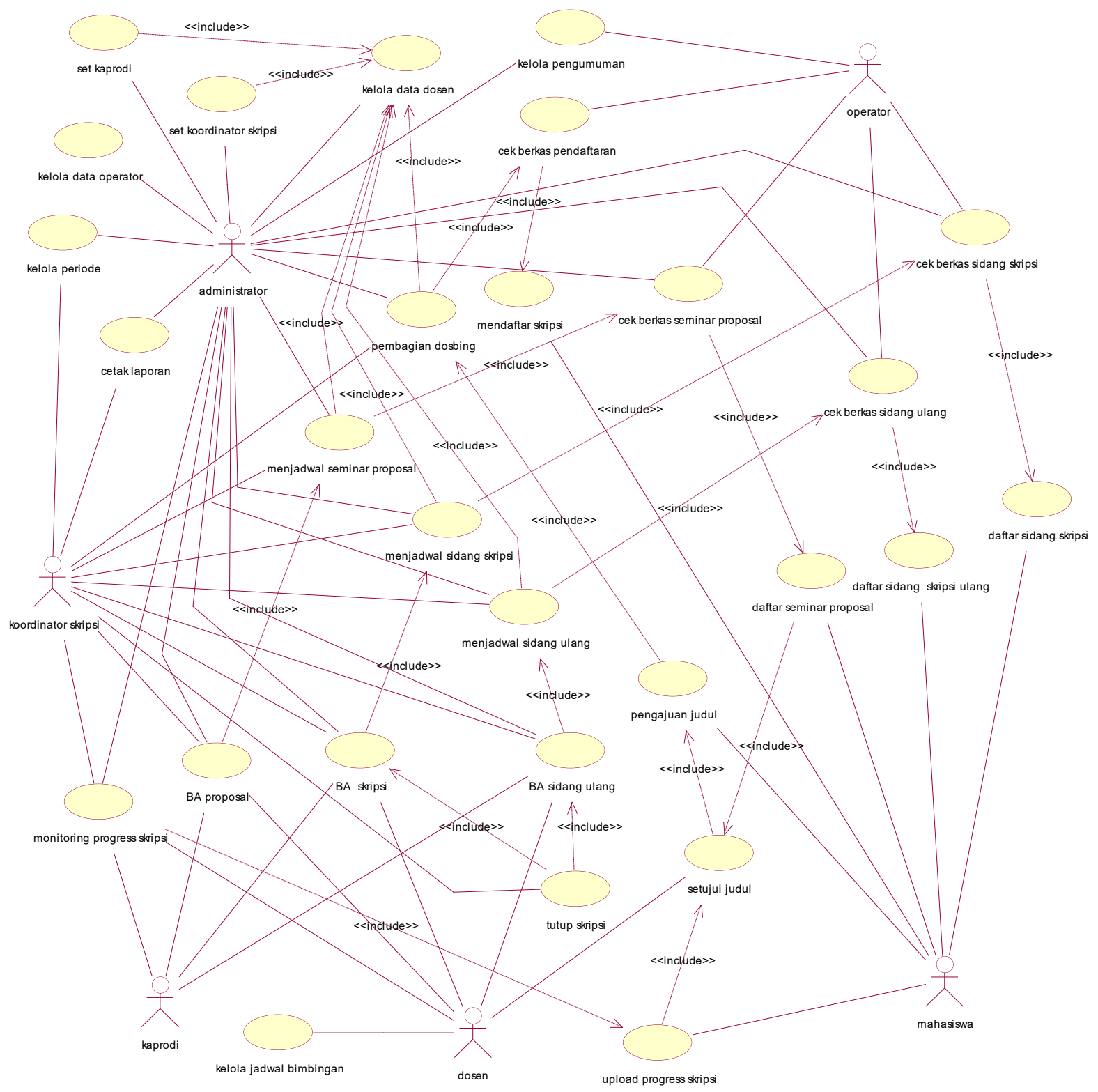

Gambar 1. Diagram Usecase Sistem Informasi Monitoring Bimbingan Skripsi 


\subsection{Perancangan Basisdata}

Basisdata yang dihasilkan berdasarkan analisa sistem adalah terdiri dari 12 (dua belas) tabel yang memiliki relasi tabel seperti pada Gambar 2.

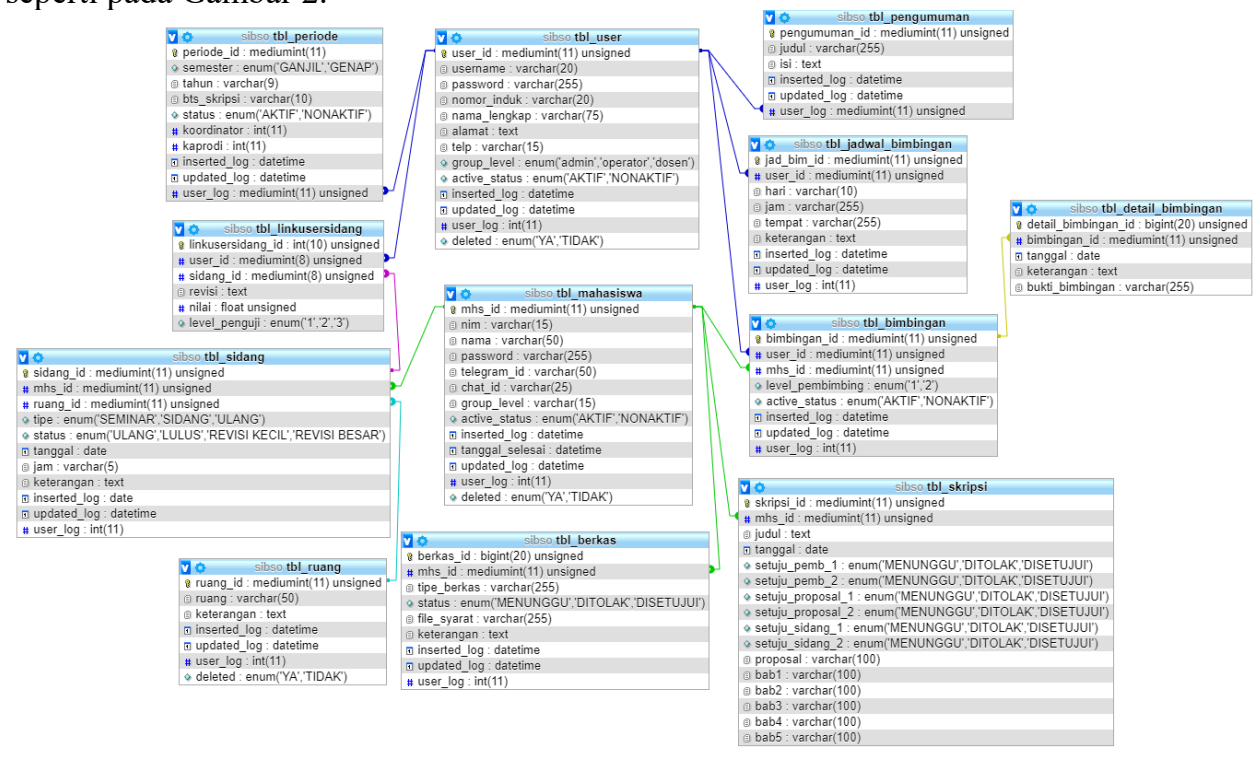

Gambar 2. Diagram Relasi Tabel Sistem Informasi Monitoring Bimbingan Skripsi

\subsection{Hasil Sistem}

Hasil analisa dan perancangan yang telah dilakukan kemudian dilakukan pengembangan Sistem Informasi Monitoring Bimbingan Skripsi menggunakan bahasa pemrograman PHP dan database MySQL. Berikut ini beberapa antarmuka dari sistem yang dibangun. Pada Gambar 3 menunjukkan antarmuka halaman pendaftaran akun bagi mahasiswa yang belum terdaftar, sedangkan mahasiswa yang sudah terdaftar dapat langsung login ke sistem.

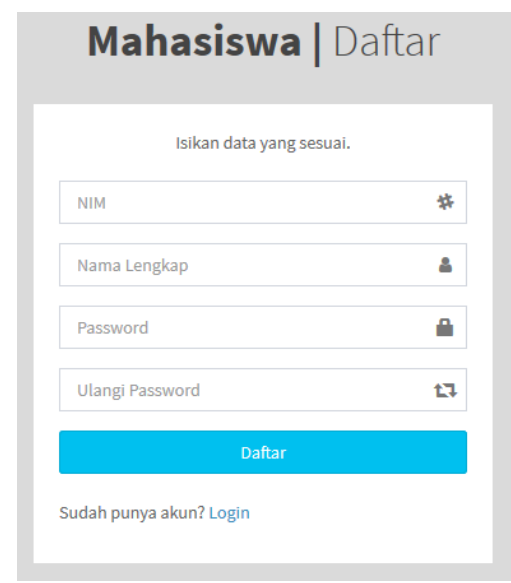

\section{Gambar 3. Antarmuka Halaman Pendaftaran Akun Mahasiswa}

Bagi mahasiswa yang sudah terdaftar dan melakukan login maka dapat mengakses beberapa menu pada Gambar 4. Mahasiswa yang akan mendaftar skripsi maka harus menyiapkan semua dokumen persyaratan dan diunggah melalui menu Upload Berkas Pendaftaran. Berkas persyaratan pendaftaran harus digabungkan dan dikompres menjadi 1 (satu) file bertipe zip atau rar. 


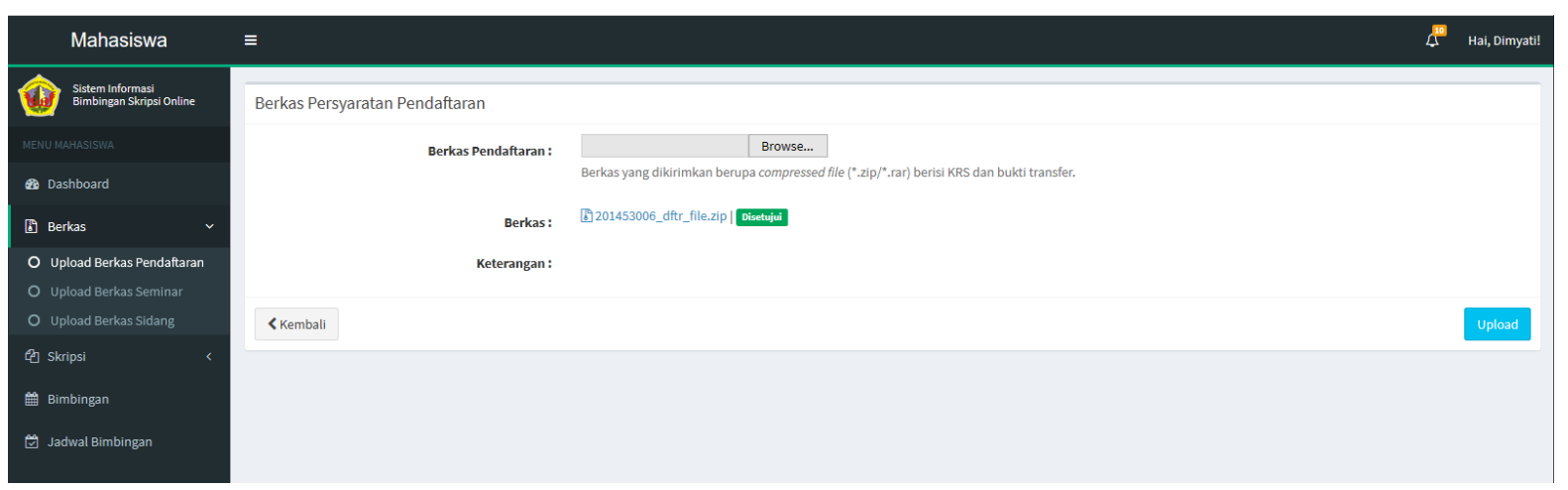

Gambar 4. Antarmuka Menu Upload Berkas Persyaratan Pendaftaran Skripsi

Berkas persyaratan pendaftaran yang sudah diunggah oleh mahasiswa kemudian dicek oleh Operator apakah berkas sudah lengkap dan sesuai atau belum. Antarmuka halaman pengecekan berkas persyaratan pendaftaran dapat dilihat pada Gambar 5.

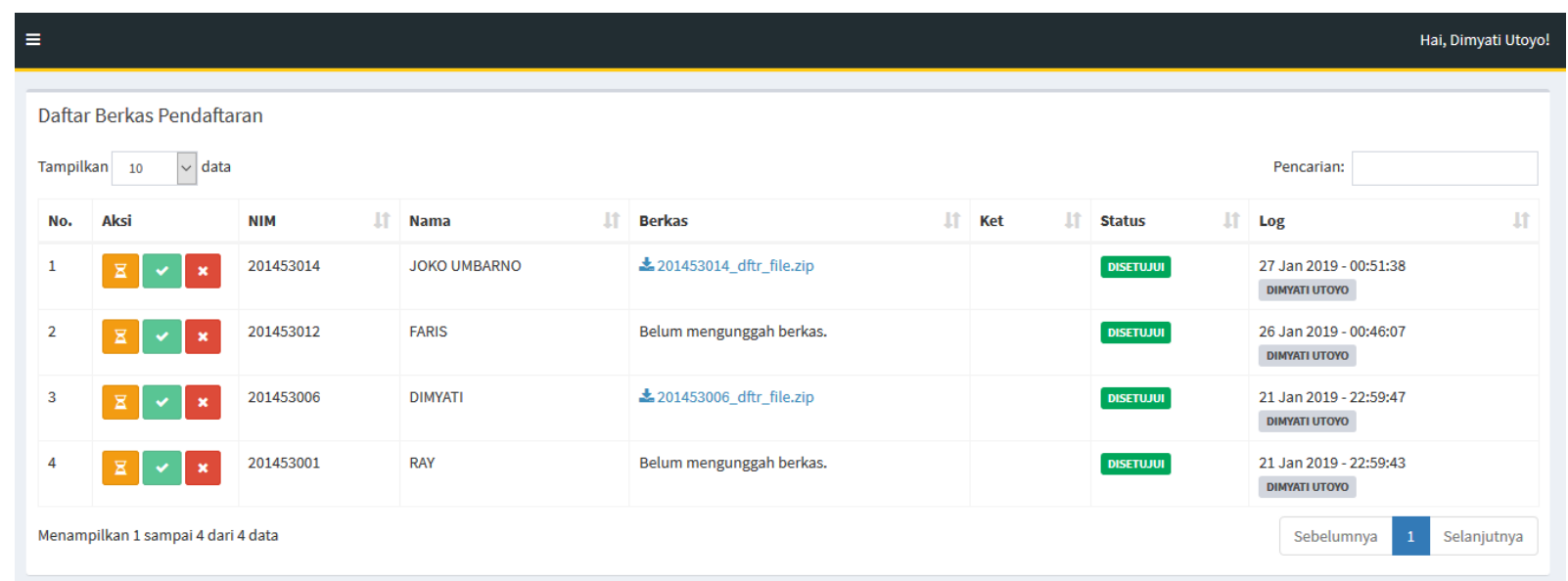

\section{Gambar 5. Antarmuka Halaman Pengecekan Berkas Persyaratan Pendaftaran}

Mahasiswa yang berkas syarat pendaftarannya telah disetujui maka akan diberi dosen pembimbing (dosbim). Setiap mahasiswa akan dibimbing oleh 2 (dua) dosbim. Proses pemberian dosen pembimbing dapat dilihat pada Gambar 6.

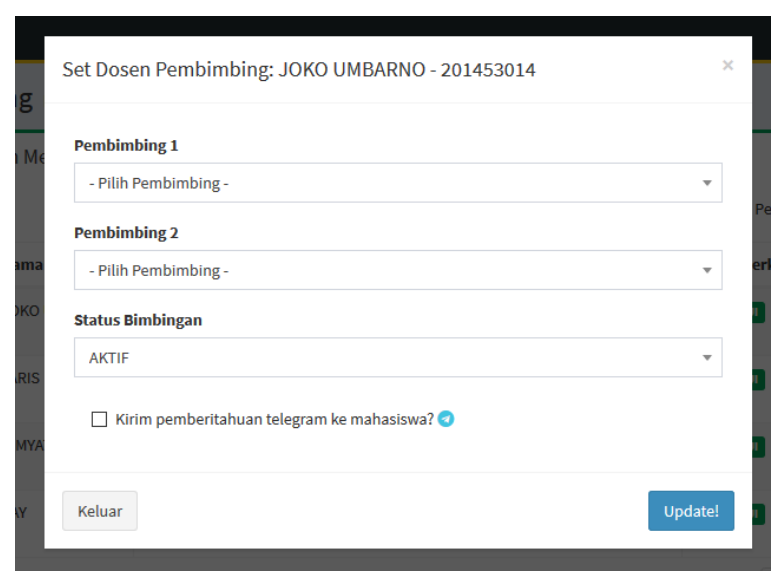

Gambar 6. Antarmuka Set Dosen Pembimbing

Setelah mendapatkan dosen pembimbing, mahasiswa dapat melakukan kegiatan bimbingan mulai dari pengajuan judul skripsi dan pelaksanaan skripsi. Judul yang diajukan oleh mahasiswa harus disetujui oleh dosen terlebih dahulu sebelum melakukan bimbingan skripsi. Apabila judul yang diajukan ditolak maka mahasiswa harus mengajukan usulan judul skripsi yang baru. Antarmuka pengajuan judul skripsi dapat dilihat pada Gambar 7 . 


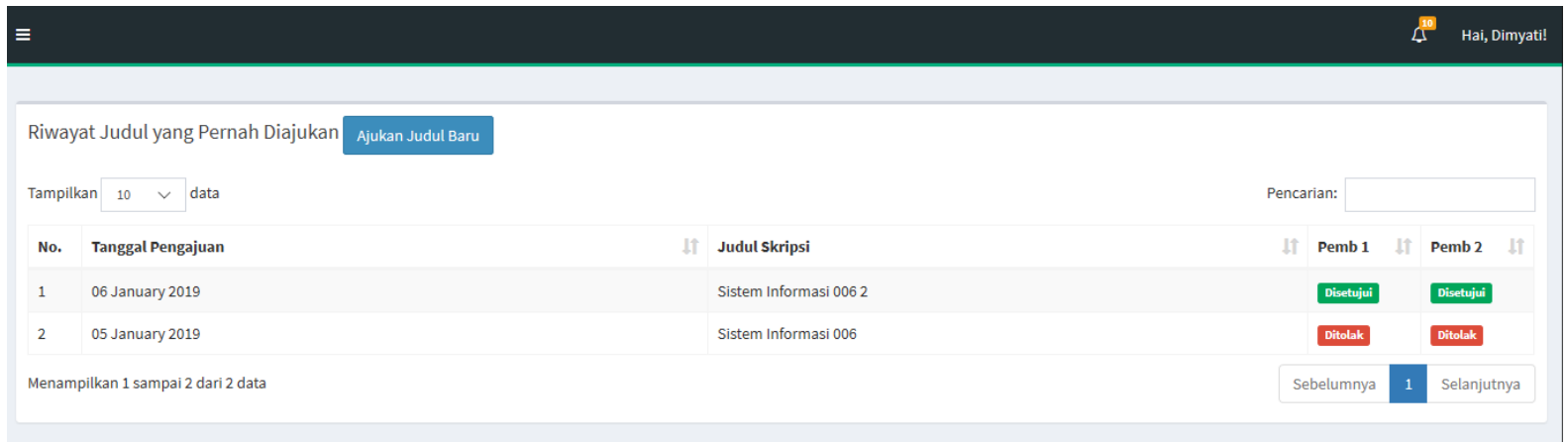

\section{Gambar 7. Antarmuka Pengajuan Judul Skripsi Oleh Mahasiswa}

Mahasiswa yang judul skripsinya telah disetujui oleh kedua dosbim dapat mulai melakukan bimbingan proposal. Setiap pelaksanaan bimbingan maka mahasiswa wajib mengunggah foto buku bimbingan melalui Sistem Informasi Monitoring Bimbingan Skripsi. Gambar 8 adalah antarmuka untuk mengunggah foto buku bimbingan sebagai bukti untuk proses monitoring bimbingan skripsi.

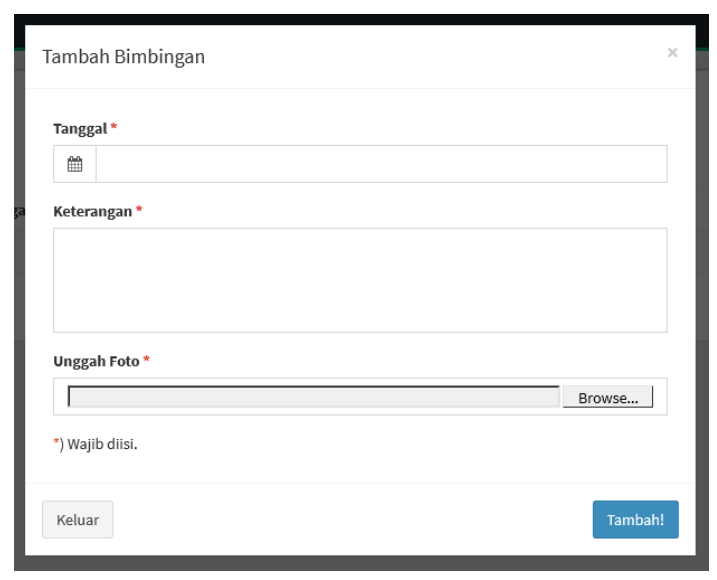

\section{Gambar 8. Antarmuka Unggah Foto Bukti Bimbingan}

Proses bimbingan skripsi yang dilakukan mahasiswa dapat dipantau atau dimonitoring oleh Dosen Pembimbing, Koordinator Skripsi, Kaprodi. Pemantauan tersebut dilakukan untuk mendorong dan memotivasi mahasiswa agar bisa menyelesaikan skripsi sesuai dengan batas waktu yang ditentukan. Gambar 9 menunjukkan antarmuka pemantauan atau monitoring bimbingan skripsi yang dilakukan mahasiswa dengan dosen pembimbinya masing-masing.

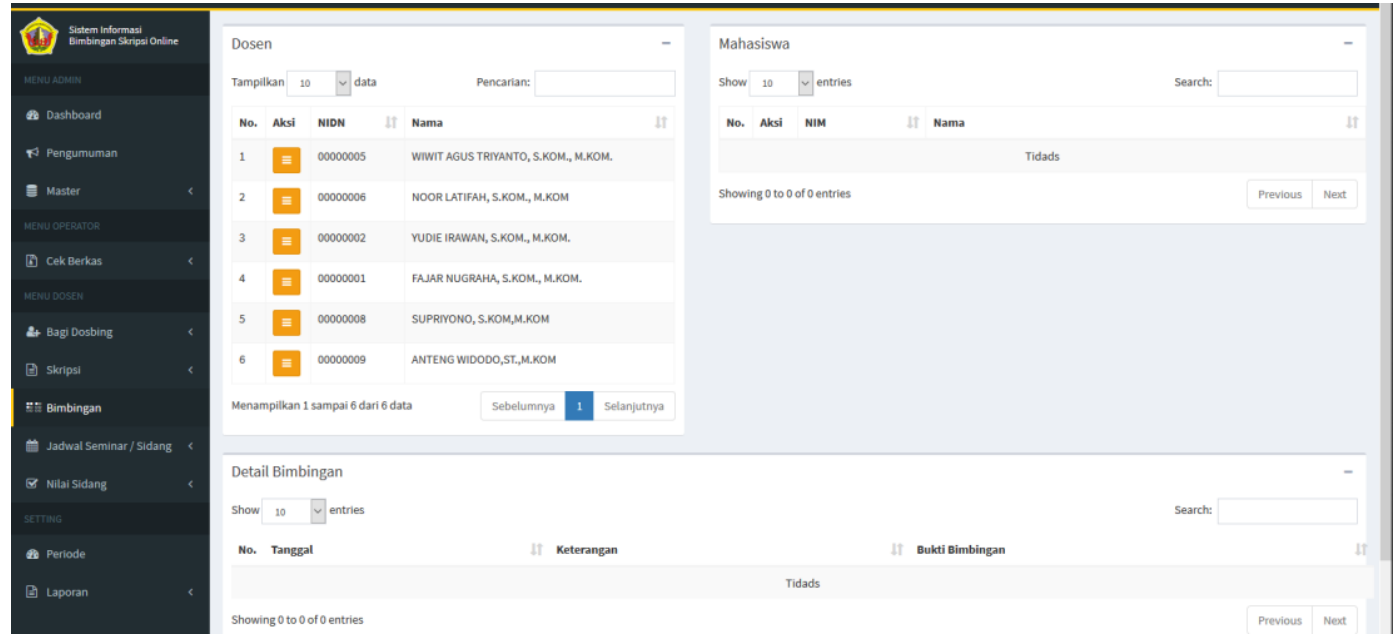

Gambar 9. Antarmuka Halaman Detil Bimbingan Skripsi Mahasiswa

Mahasiswa yang telah melakukan bimbingan proposal skripsi kemudian mendaftar seminar proposal melalui Sistem Informasi Monitoring Bimbingan Skripsi dengan mengunggah berkas seminar proposal melalui menu Upload Berkas Seminar seeprti pada Gambar 10. Berkas syarat pendaftaran seminar proposal harus digabungkan dan dikompres menjadi 1 (satu) file bertipe zip atau rar. 


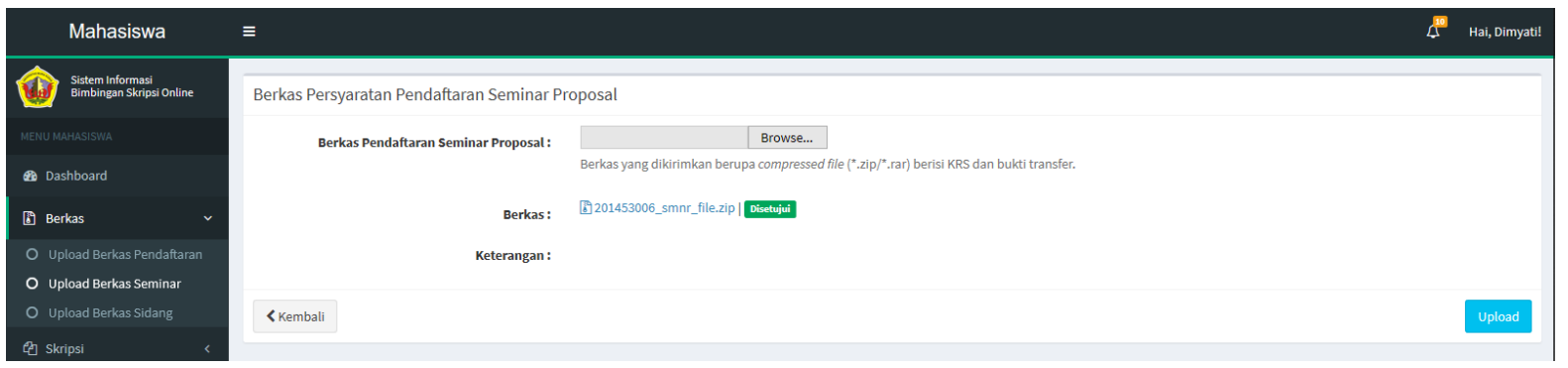

\section{Gambar 10. Antarmuka Upload Berkas Seminar Proposal}

Data pendaftaran seminar proposal kemudian dijadwalkan pelaksanaan seminar proposal oleh Koordinator Skripsi dengan memilih daftar dosen penguji seperti pada Gambar 11. Dosen penguji proposal terdiri dari 2 (dua) orang dosen pembimbing ditambah 1 (satu) orang dosen penguji.

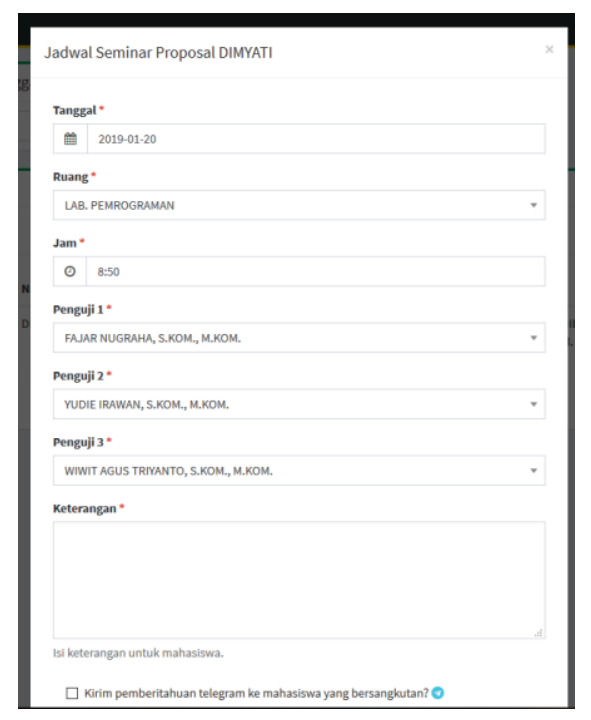

\section{Gambar 11. Antarmuka Pembuatan Jadwal Seminar Proposal}

Penilaian apakah suatu proposal skripsi layak disetujui atau tidak ditentukan pada saat pelaksanaan seminar proposal. Dewan penguji proposal akan memberikan nilai hasil seminar dan memberikan status apakah proposal tersebut layak disetujui, disetujui dengan revisi, atau bahkan ditolak. Nilai yang telah dimasukkan oleh dosen penguji melalui sistem dapat dilihat pada rekapitulasi nilai seminar pada halaman hak akses Koordinator Skripsi seperti pada Gambar 12.

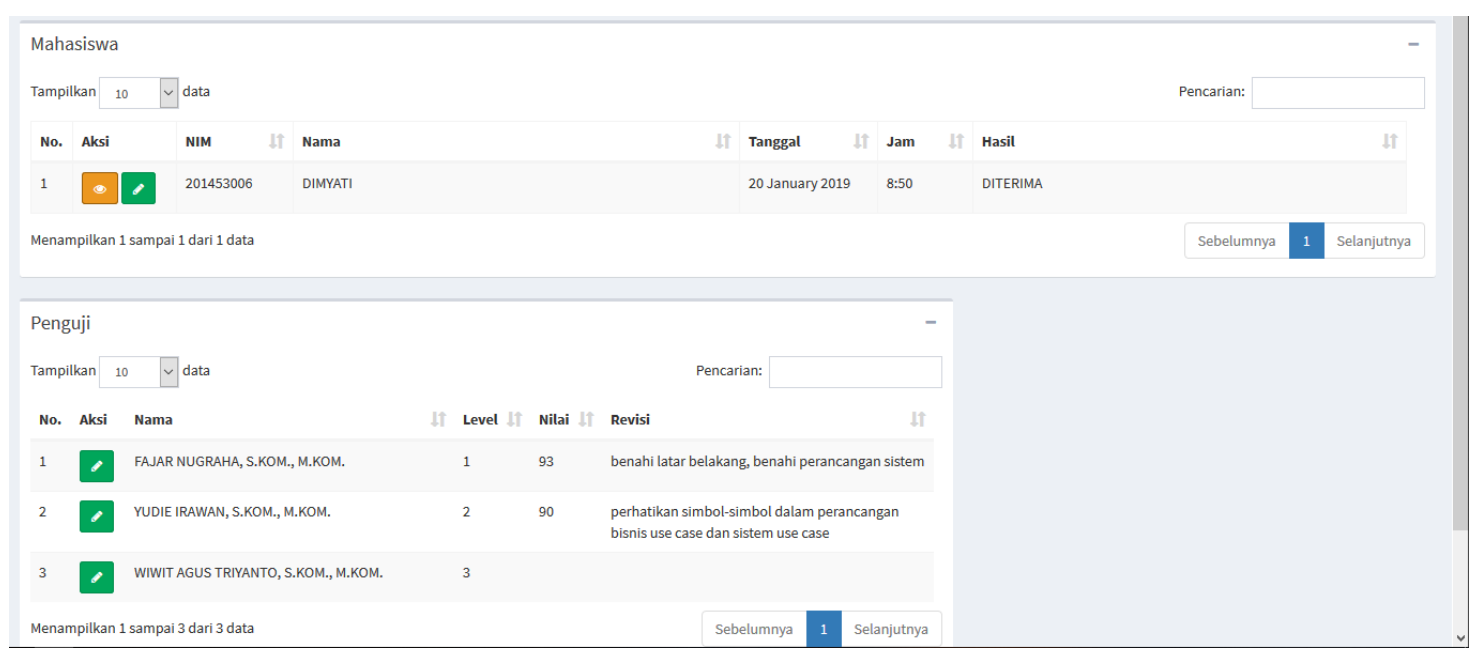

Gambar 12. Antarmuka Rekapitulasi Penilaian Seminar Proposal

Proposal skripsi yang diterima atau disetujui maka dilanjutkan ke tahap pelaksanaan skripsi meliputi bimbingan skripsi, pengembangan dan pengujian sistem. Setelah skripsi selesai dan disetujui oleh dosen pembimbing untuk mendaftar sidang skripsi, maka mahasiswa harus melakukan pendaftaran sidang skripsi melalui 
Sistem Informasi Monitoring Bimbingan Skripsi dengan mengunggah berkas syarat pendaftaran sidang skripsi yang telah dikompres menjadi 1 (satu) file bertipe zip atau rar seperti terlihat pada Gambar 13. Mahasiswa yang sudah mendaftar sidang skripsi kemudian dijadwalkan pelaksanaan sidang skripsi oleh Koordinator Skripsi dengan memilih daftar dosen penguji seperti pada Gambar 14. Dosen penguji sidang skripsi terdiri dari 1 (satu) orang dosen pembimbing ditambah 2 (dua) orang dosen penguji.

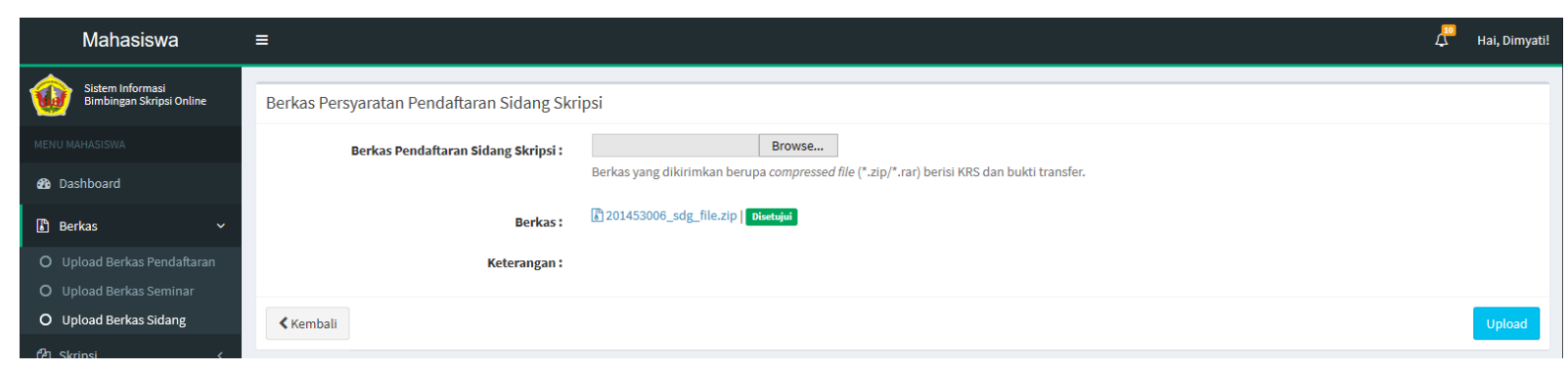

Gambar 13. Antarmuka Upload Berkas Sidang Skripsi

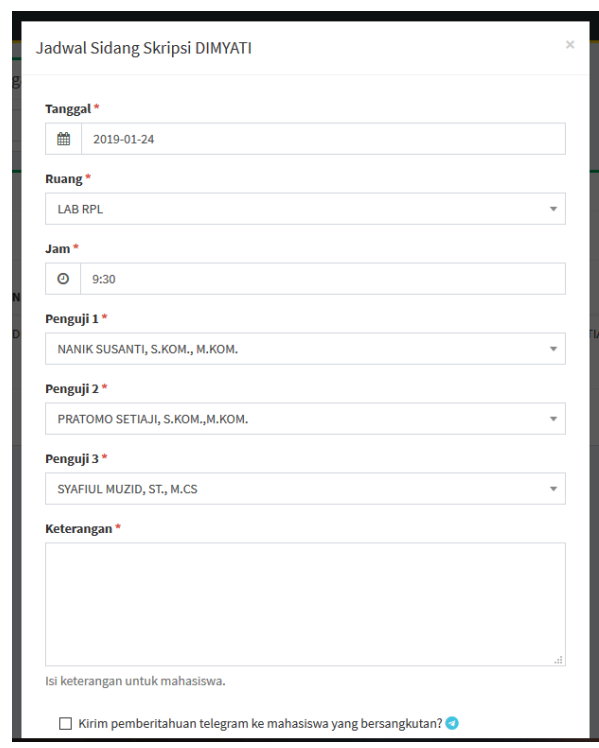

\section{Gambar 14. Antarmuka Pembuatan Jadwal Sidang Skripsi}

Setelah pelaksanaan sidang skripsi, dewan dosen penguji kemudian memasukkan nilai dam revisi hasil sidang skripsi melalui Sistem Informasi Monitoring Bimbingan Skripsi. Nilai yang telah dimasukkan akan terekap didalam sistem dan digunakan untuk menentukan nilai akhir dari skripsi mahasiswa. Rekapitulasi detil penilaian sidang skripsi dapat dilihat pada Gambar 15.

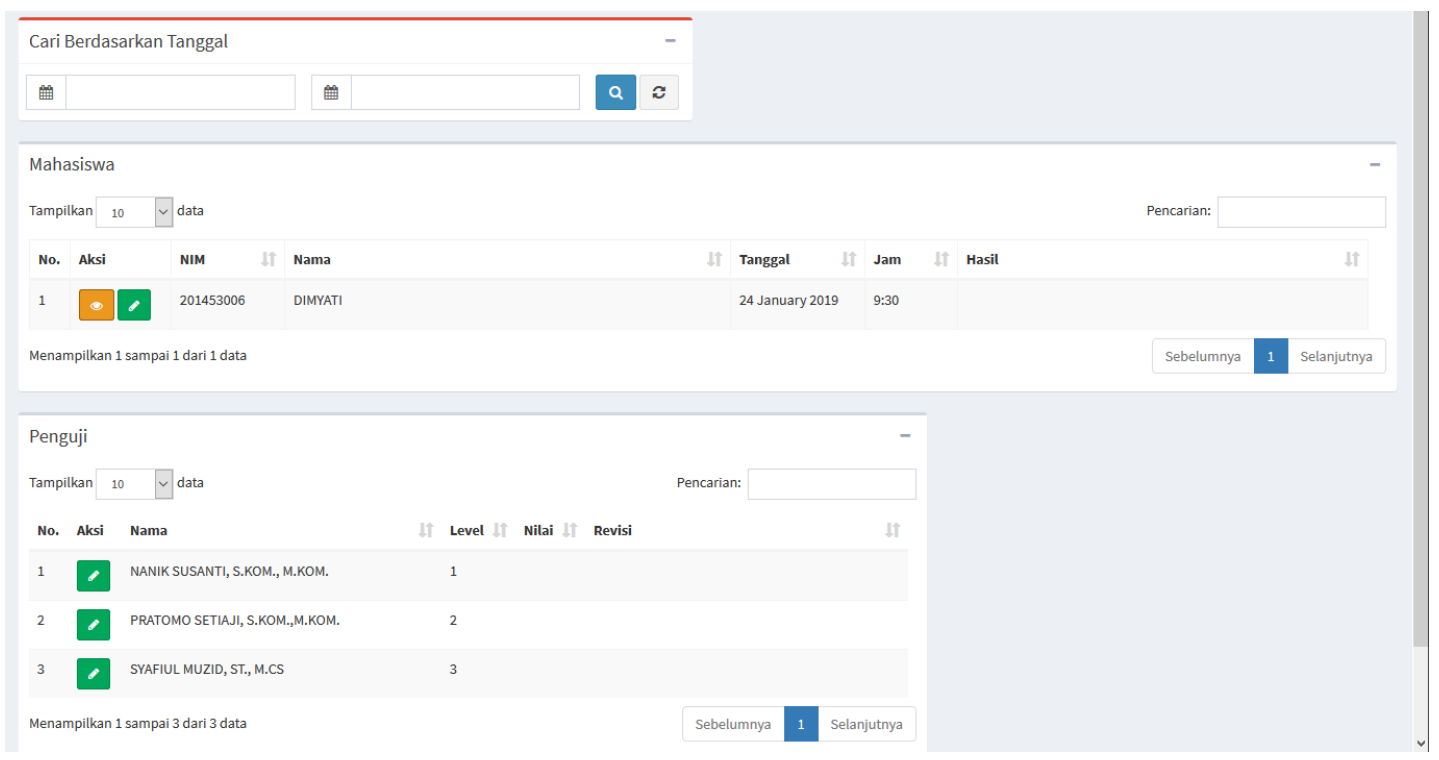

Gambar 15. Antarmuka Detil Penilaian Sidang Skripsi 
Informasi terkait jadwal bimbingan dosen, jadwal seminar proposal dan jadwal sidang skripsi serta status kelulusan dapat dilihat oleh mahasiswa melalui menu Dashboard setiap mahasiswa seperti pada Gambar 16.

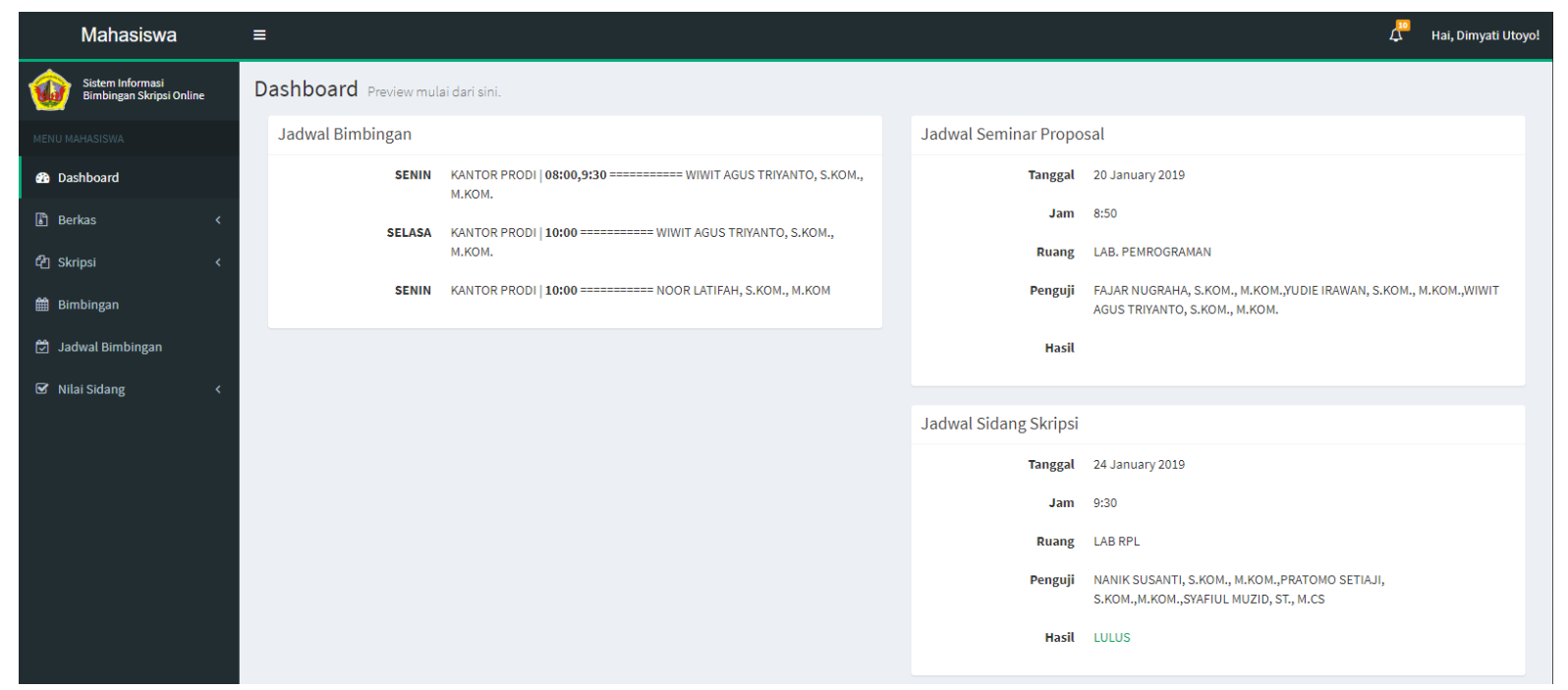

Gambar 16. Antarmuka Dashboard Mahasiswa Yang Berisi Informasi Jadwal Bimbingan, Jadwal Seminar Proposal Dan Jadwal Sidang Skripsi

\section{KESIMPULAN}

\subsection{Kesimpulan}

Berdasarkan dari hasil penelitian Sistem Informasi Monitoring Bimbingan Skripsi maka dapat diambil beberapa kesimpulan sebagai berikut:

1) Sistem Informasi Monitoring Bimbingan Skripsi dapat digunakan untuk membantu dosen pembimbing dalam melakukan pengawasan atau monitoring terhadap mahasiswa bimbingannya agar lebih terkontrol.

2) Sistem ini membantu koordinator skripsi untuk melakukan pembagian dosen pembimbing dan dosen penguji serta penjadwalan seminar proposal, sidang skripsi, dan sidang ulang.

3) Sistem ini membantu mahasiswa dalam mengetahui sisa waktu pengerjaan skripsi sehingga memberikan motivasi agar segera menyelesaikan skripsi sesuai dengan batas waktu yang ditentukan.

\subsection{Saran}

Penelitian ini masih banyak memiliki kekurangan sehingga perlu dilakukan penelitian lebih lanjut. Berikut beberapa saran untuk penelitian selanjutnya:

1) Seiring dengan perkembangan teknologi informasi, diharapkan adanya pengembangan aplikasi berbasis mobile.

2) Diharapkan adanya fitur chat yang terintegrasi dengan Whatsapp atau yang lainnya sehingga memudahkan dalam mengirimkan informasi.

3) Diharapkan adanya fitur pembagian dosen pembimbing dan penjadwalan sidang secara acak sehingga proses tersebut dapat dilakukan secara otomatis melalui sistem.

\section{DAFTAR PUSTAKA}

[1] Aplikasi Bimbingan Skripsi Online Mahasiswa Jurusan Pendidikan Matematika Fakultas Matematika dan Ilmu Pengetahuan Alam Universitas Negeri Yogyakarta (Perdana, 2014)

[2] Ramayasa, I. P., \& Arnawa, I. B. (2015). Perancangan Sistem Monitoring Pengerjaan Skripsi pada Stmik Stikom Bali Berbasis Web. Konferensi Nasional Sistem \& Informatika.

[3] Ramadhan, M. R., Nugroho, L. E., \& Sulistyo, S. (2017). Perancangan Sistem Informasi Monitoring Skripsi. CITEE.

[4] Utariani, \& Herkules. (2017). Monitoring Bimbingan Skripsi Online pada Sekolah Tinggi Manajemen Informatika dan Komputer (STMIK) Palangkaraya. Jurnal Saintekom.

[5] Pressman. R., 2002, Software Engineering : Practical Approach, Wembley-Hills, New York.

[6] Podeswa, H., 2006, UML for the IT Business Analyst: A Practical Guide to Object-Oriented Requirements Gathering, Thomson Course Technology PTR, Boston

[7] Sukamto, R. A., Shalahuddin, M. (2016). Rekayasa Perangkat Lunak Terstruktur dan Berorientasi Objek. Bandung: Informatika Bandung. 